\title{
PERFORMANCE AND UTILITY OF AN ORAL FLUID-BASED RAPID POINT-OF- CARE TEST FOR SARS-COV-2 ANTIBODY RESPONSE FOLLOWING COVID-19 INFECTION OR VACCINATION
}

\author{
Paturi V. Rao ${ }^{1,2}$, Dhanalakshmi Nair-Shaef ${ }^{1,2}$, Siting Chen ${ }^{3}$, Steven C. Kazmierczak ${ }^{3}$, \\ Charles T. Roberts, Jr. ${ }^{1,2}$, Srinivasa R. Nagalla ${ }^{1,2}$ \\ ${ }^{1}$ Diabetomics, Inc., Hillsboro, OR 97006 \\ ${ }^{2}$ COVYDx, Inc., Hillsboro, OR 97006 \\ ${ }^{3}$ Oregon Health \& Science University, Portland OR 97239
}

\begin{abstract}
Analysis of anti-SARS-CoV-2 antibodies can identify recent-onset or prior COVID-19 infection or vaccine-induced humoral immunity. We have developed a rapid point-of-care test for IgG, $\mathrm{M}$, or A-class immunoglobulins that recognize the S1 domain of the SARS-CoV-2 spike protein $\left(\mathrm{CovAb}^{\mathrm{TM})}\right.$. The test employs a lateral-flow strip design with a recombinant SARS-CoV-2 spike protein S1 domain capture antigen to detect anti-SARS-CoV-2 antibodies in oral fluid samples. Oral fluid samples are collected with a swab that captures the gingival crevicular fluid component of oral fluid that represents a plasma transudate and that is the primary source of oral fluid monomeric antibodies. The sensitivity of the CovAb ${ }^{\text {TM }}$ test is $97.29 \%$ and the specificity is $98.13 \%$, and the results obtained are similar to those obtained using matched fingerstick whole blood samples and in an EUA-approved commercial serology test. Oral fluid SARS-CoV-2 antibodies could be detected in subjects more than 7 months post-symptom onset. We also demonstrate the utility of the CovA ${ }^{T M}$ test in characterizing adaptive immune responses to vaccination in COVID-19-naïve and exposed populations after first and second vaccine doses and show that significant heterogeneity in magnitude of antibody titers achieved is seen after both doses and that prior COVID-19 exposure increases the adaptive immune response to vaccination.
\end{abstract}


medRxiv preprint doi: https://doi.org/10.1101/2021.06.28.21259657; this version posted July 3, 2021. The copyright holder for this preprint (which was not certified by peer review) is the author/funder, who has granted medRxiv a license to display the preprint in perpetuity.

All rights reserved. No reuse allowed without permission.

\section{INTRODUCTION}

The COVID-19 pandemic caused by the novel SARS-CoV-2 coronavirus (1) has created a worldwide need for effective diagnostics to enable identification and contact tracing of infected individuals to administer appropriate clinical care as necessary and to contain further disease spread, as well as to assess serological responses to infection and vaccines (2-4). PCR-based methods for detection of viral nucleic acid are sensitive but require centralized laboratory facilities, an appreciable turnaround time, and do not reliably identify disease experienced more that 14 days before testing nor the presence of neutralizing antibodies that may indicate immunity. Antigen tests that detect SARS-CoV-2 viral proteins are more amenable to rapid, point-of-care designs, but are less sensitive than PCR tests and also only identify ongoing or recent disease and do not reveal the presence of COVID-19 antibodies.

Tests specifically designed to detect anti-SARS-CoV-2 antibodies can provide information on the adaptive immune response to recent disease or vaccination, but test performance can be variable $(5,6)$, although some tests exhibit high sensitivity and specificity (7-10). There are a number of possible test designs that influence the type of information obtained. Major variables include the capture antigen (nucleocapsid vs spike protein S1 and/or S2 domains vs receptorbinding domain), the immunoglobulin class detected (IgG, M, or A), the clinical sample source (blood, serum, plasma, or oral fluid), and the analytical design (ELISA/chemiluminescent immunoassay, lateral-flow, etc.). A spike protein receptor-binding domain-based test would be more likely to detect potential neutralizing antibodies as they would interfere with viral attachment to target cells (11). In support of this concept, the most potent neutralizing antibodies isolated from convalescent COVID-19 patients target the SARS-CoV-2 spike protein, particularly the receptor-binding domain (12-14). Additionally, the S1 domain (which includes the receptor-binding domain) is less conserved that the $S 2$ domain or nucleocapsid between seasonal SARS and SARS-CoV-2, thus making the use of the S1 or receptor-binding domain for antibody capture potentially more specific for COVID-19 (15). The various detection platforms include standard PCR instruments for nucleic acid detection, plate or automated analyzer platforms for ELISA/chemiluminescent assays, and lateral-flow devices for some rapiddetection tests.

Several lateral-flow COVID-19 serology tests have been developed that employ fingerstick whole blood samples and that exhibit good performance (16), including in a point-of-care (POC) setting (17). While the majority of current tests utilize a nasopharyngeal swab for PCR testing or a blood sample (whole blood, serum, or plasma) for antigen and antibody testing, saliva has emerged as a noninvasive alternative for SARS-CoV-2 nucleic acid $(18)$ and antigen $(19,20)$ detection based on SARS-CoV-2 infection of the oral cavity (21) enabled by oral cavity expression of SARS-CoV-2 entry molecules (22). Saliva has also been reported to be a source of SARS-CoV-2 antibodies (23-26). Our approach was to utilize the optimal combination to produce a simple, sensitive, cost-effective, rapid POC design for detection of anti-SARS-CoV-2 antibodies in oral fluid, specifically the gingival crevicular fluid (GCF) that is a transudate of plasma (27-28), and which is increasingly appreciated as an important source of diagnostic biomarkers (29-33). The use of GCF as the assay fluid enables a completely non-invasive format. This test (CovAb ${ }^{\mathrm{TM}}$ ) employs a recombinant SARS-CoV-2 spike protein $\mathrm{S} 1$ domain as a capture antigen and a lateral-flow strip that detects IgG, A, and $M$ immunoglobulins, since all three immunoglobulin classes are components of the SARS-CoV-2-induced adaptive immune response $(34,35)$. 
medRxiv preprint doi: https://doi.org/10.1101/2021.06.28.21259657; this version posted July 3, 2021. The copyright holder for this preprint (which was not certified by peer review) is the author/funder, who has granted medRxiv a license to display the preprint in perpetuity.

All rights reserved. No reuse allowed without permission.

\begin{abstract}
METHODS AND RESULTS $\operatorname{CovAb}^{\mathrm{TM}}$ test design

Oral fluid SARS-CoV-2 antibodies were assayed using the CovAb ${ }^{\mathrm{TM}}$ SARS-CoV-2 Ab test (FDA EUA authorization \#210017 dated 6/4/2021), a lateral-flow immunochromatography assay. Recombinant SARS-Cov-2 spike protein S1 domain produced in human embryonic kidney HEK293 cells (Diabetomics, Inc.) and goat anti-human IgG, IgA, and IgM (Jackson ImmunoResearch Laboratories, Inc.) were used for capture and detection of SARS-CoV-2 antibodies. For quantification of antibody levels shown in Tables 8 and 9 and Figures 1-3, a proprietary lateral-flow quantification reader based on image capture technology (Diabetomics, Inc.) was used. Samples that registered above 70 reflectance units with the reader were considered positive based on the maximal level observed in 160 SARS-CoV-2 RT-PCRnegative GCF samples.
\end{abstract}

\title{
Cross-reactivity/analytical specificity studies
}

Cross-reactivity with virus, bacteria, and auto-antibodies. Serum or plasma samples validated for the presence of antibodies to specific pathogens (BiolVT, NY) were spiked into negative GCF samples and tested for cross-reactivity with the CovAbTM test. The pathogens tested included influenza A, influenza B, Haemophilus influenza, respiratory syncytial virus (RSV), hepatitis $C$ virus (HCV), hepatitis $B$ virus (HBV), human immunodeficiency virus (HIV), alpha coronavirus 229E, alpha coronavirus NL63, beta coronavirus OC43, beta coronavirus HKU1, enterovirus, M. pneumoniae, C. pneumoniae, B. pertussis, Parainfluenza 1-4, and rheumatoid factor (RF). As shown in Table 1, there was no cross-reactivity of any of the samples with the CovAb ${ }^{T M}$ test.

Interference by exogenous substances.

The $\operatorname{CovAb^{TM}}$ test uses an oral fluid specimen (primarily GCF). Robustness testing included the testing of exogenous substances that may be expected to be consumed orally. Substances tested included ethanol, nicotine, hot caffeinated beverages (coffee and tea), carbonated sodas (Coca-Cola), orange juice, mouthwash (Listerine), and cough syrup (Nyquil Cough DM+, spiked at $7 \%$ total volume). In brief, stocks of nicotine, ethanol, and cough syrup were made and diluted in pooled GCF to obtain testing matrices containing these interferents. For the other potential interferents, volunteers used or consumed the potential interferents prior to sampling. Each matrix was then tested with 5 negatives, 5 low positives, and one high positive. GCF samples were collected from six different individuals before consuming the interferent, immediately after consuming the interferent, and 30 minutes after consuming the interferent (total of 3 testing points). None of these substances affected the development of the control or test lines (data not shown).

\section{Clinical agreement studies using oral fluid}

In a prospective clinical study, 306 subjects were enrolled at 4 study sites (Oregon Health \& Science University, Portland, OR; two institutional hospitals in Hyderabad, Telangana, India, dedicated for COVID-19 care, the Asian Institute of Gastroenterology (AIG) and Sunshine specialty hospitals (SUNSEC); and at two nursing homes in Seattle, WA) to collect GCF samples for testing. Samples were obtained at early (2-7 days from onset of symptoms), intermediate (8-14 days), and convalescent (>14 days) stages of disease. 146 subjects were SARS-CoV-2 RT-PCR-positive and 160 subjects were SARS-CoV-2 RT-PCR-negative based on CDC emergency use authorization (EUA)-approved RT-PCR tests. The demographics of the study population are shown in Table 2 . The positive percent agreements (PPA) and negative percent agreements (NPA) are shown in Table 3, with the positive cases distributed by days from symptom onset. This study showed that, in the early-onset stage, antibody levels are low and variable, and increase at the intermediate stage with a higher percent positivity. In the 
medRxiv preprint doi: https://doi.org/10.1101/2021.06.28.21259657; this version posted July 3, 2021. The copyright holder for this preprint (which was not certified by peer review) is the author/funder, who has granted medRxiv a license to display the preprint in perpetuity.

All rights reserved. No reuse allowed without permission.

convalescent stage, seroconversion is complete and a high percentage of subjects developed detectable levels of antibodies. This study demonstrated $97.29 \%$ PPA agreement in seroconverted subjects (>14 days from onset of symptoms) and $98.13 \%$ NPA.

We also determined the persistence of oral fluid antibodies in the antibody-positive subjects. As shown in Table 4, the CovAb ${ }^{\mathrm{TM}}$ test detected antibodies up to 7.2 months post-symptom onset in $>8 \%$ of the antibody-positive group.

\section{Comparison of oral fluid with fingerstick sample and with RT-PCR test status.}

A subset of the subjects $(n=83)$ from the US nursing home study population provided fingerstick whole blood samples. This study set included 54 subjects who tested positive for SARS-CoV-2 and 29 subjects who tested negative for SARS-CoV-2 by an RT-PCR test. As shown in Table 5, there was $98 \%$ PPA between the CovAb ${ }^{T M}$ fingerstick test and RT-PCR-positive status and $100 \%$ PPA between the CovA ${ }^{\mathrm{TM}}$ fingerstick and GCF samples.

\section{Comparator EUA serology test (Siemens total antibody test)}

Fingerstick whole-blood samples were obtained from 38 subjects who tested positive with the CovA ${ }^{\mathrm{TM}}$ test using GCF, and all were also positive in the CovAb ${ }^{\mathrm{TM}}$ test using these whole blood samples. 36 of the fingerstick samples had sufficient volume to also be tested with an US FDA EUA-authorized serology test (Siemens total antibody test). This test uses the same spike protein $\mathrm{S} 1$ domain for capture as the CovAb ${ }^{T M}$ test, and exhibits high specificity and sensitivity in head-to-head comparisons with other commercial serology tests (7). As shown in Table 6 , there was excellent agreement between the two tests for 35/36 samples, with 1 sample that was RT-PCR-positive and positive in the CovA ${ }^{\mathrm{TM}}$ test being negative in the Siemens test (CovAb ${ }^{\mathrm{TM}}$ test PPA, 100\%; Siemens test PPA >97\%).

\section{Assessment of post-vaccination antibody responses}

A prospective study of 160 subjects was conducted to examine post-vaccination antibody responses at Ramadev Rao Hospital, Telengana, Hyderbad, India. 77 COVID-19-naïve subjects who tested negative with the CovAb ${ }^{T M}$ test prior to screening were tested at 28-29 days after the first dose of the Oxford-AstraZeneca vaccine (Covishield). 57 subjects from the same cohort were tested 14 days after the second dose of the vaccine. 83 subjects who were exposed to COVID-19 (clinical laboratory staff performing COVID-19 testing at Tennet Diagnostics, Hyderabad, India; the COVID-19-exposed group) was tested at 18-20 days after the first dose of the vaccine. The demographics of these groups are shown in Table 7 . The median, $25^{\text {th }}$, and $75^{\text {th }}$ percentile response values, and the interquartile range (IQR) for the positive samples in the three groups (with reflectance unit readings $>70$ ) are shown in Table 8.

The response of the COVID-19-naïve group to the first vaccine dose is shown in Figure 1A. Of this group, $24(33 \%)$ were antibody-negative and $53(67 \%)$ were antibody-positive, with a median response of 488 reflectance units (Table 8). The response of the COVID-19-exposed group to the first vaccine dose is shown in Figure 1B. Of this group, 32 (37\%) were antibodynegative and 51 (63\%) were antibody-positive, a proportion similar to the COVID-19-naïve group. However, as illustrated by the comparison of the responses of the COVID-19-naïve and exposed groups shown in Figure 1C, the response of the COVID-19-exposed group was more robust, with a median response of 1163 reflectance units, and more evenly distributed, with a larger IQR (Table 8), and as illustrated in Figure 2, the difference in the median response in antibody-positive COVID-naïve subjects was significantly greater that that seen in the COVID19-naïve group $(p=0.0005)$. 
medRxiv preprint doi: https://doi.org/10.1101/2021.06.28.21259657; this version posted July 3, 2021. The copyright holder for this preprint (which was not certified by peer review) is the author/funder, who has granted medRxiv a license to display the preprint in perpetuity.

All rights reserved. No reuse allowed without permission.

The response of the COVID-19-naïve group to a second vaccine dose is shown in Figure 1D. In this group, 7 (14\%) were antibody-negative and 50 (86\%) were antibody-positive, representing a higher rate of antibody response vs the first dose (86 vs $67 \%$ ). However, as also illustrated in Figure 2, there was no statistically significant difference between the median antibody responses of the COVID-naïve group to the first and second doses of vaccine $(p=0.44)$, although this may reflect the shorter post-vaccination interval for the second dose (i.e., 14 vs 28-29 days).

We also investigated the effect of sex on vaccine responses. As shown in Table 9, the rate of positive responses in all three groups was greater for females that males ( 77 vs $62 \%, 78$ vs $53 \%$, and 96 vs $82 \%$, respectively, in the COVID-19-naïve dose 1, COVID-exposed dose 1, and COVID-19-naïve dose 2 groups. The median response was also greater in females than males in the COVID-19-naïve dose 1 and COVID-19-naïve dose 2 groups (799 vs 296.5 and 499.5 vs 299, respectively), while the median response of females and males in the COVID-exposed dose 1 group was similar (1075 vs 1255.5). However, as shown in Figure 3, these differences were not statistically significant, although the trend toward a sex difference was more apparent in the COVID-19-naïve dose 1 and dose 2 groups.

\section{DISCUSSION}

In this study, we describe the performance of a novel, rapid, oral-fluid-based diagnostic device $\left(\mathrm{CovAb}^{\mathrm{TM}}\right)$ for determination of infection or vaccine-induced anti-SARS-CoV-2 antibodies. We evaluated test performance in two distinct COVID-19 patient populations, one in the US and one in India. Our findings demonstrate that the CovAb ${ }^{\mathrm{TM}}$ test exhibits similar performance in both geographical populations and generates results in accordance with the commercial blood-based serology test. We also investigated antibody responses in both COVID-naïve and COVIDexposed (nursing home staff) groups as well as responses to first and second doses of vaccine in the COVID-naïve group. We found that there was a wide range of response after both the first and second dose of the Oxford-AstraZeneca vaccine, with significant numbers of vaccinated individuals lacking a detectable response, even following a second dose, although the antibody response was greater following the second dose. A more robust serology response to the second dose has also been recently reported for mRNA vaccines (36). We also found that antibody responses were more prevalent and robust in a group with prior exposure to COVID-19 patients. An enhanced serology response to mRNA vaccination in previously infected individuals has been reported $(37,38)$, but this appears to be the first report of enhanced response in asymptomatic COVID-exposed individuals.

The CovAb ${ }^{\text {TM }}$ test employs an oral fluid sample enriched in GCF vs saliva. While SARS-CoV-2 antibodies have been reported in saliva following infection, those saliva samples presumably included GCF, since most saliva collection protocols for diagnostic testing do not obtain pure saliva. Our preliminary data comparing GCF vs saliva-enriched oral fluid indicate that GCF is the major source of the SARS-CoV-2 antibodies detected with the CovAb ${ }^{T M}$ test, consistent with its characterization as a plasma transudate and which is responsible for oral fluid $\lg \mathrm{g}, \lg \mathrm{M}$, and monomeric $\lg \mathrm{A}(39)$.

The CovAb ${ }^{T M}$ test, by virtue of its POC format, noninvasive sample collection, and rapid time frame, should be of general use for detection of previous (within several months) infection or initial adaptive immune response to vaccination. Verification of effective post-vaccination antibody response will be important to determine the need for use of a different vaccine, or booster of the same vaccine, and to predict the likelihood of subsequent memory $B$ cell development responsible for long-term immunity $(40,41)$. 
medRxiv preprint doi: https://doi.org/10.1101/2021.06.28.21259657; this version posted July 3, 2021. The copyright holder for this preprint (which was not certified by peer review) is the author/funder, who has granted medRxiv a license to display the preprint in perpetuity.

All rights reserved. No reuse allowed without permission.

\section{REFERENCES}

1. World Health Organization. 2020. WHO coronavirus disease (COVID-19) dashboard. https://covid19.who.int.

2. Gudbjartsson DF, Norddahl GL, Melsted P, Gunnarsdottir K, Holm H et al. Humoral immune response to SARS-CoV-2 in Iceland. New Eng J Med. 2020;383:1724-1734.

3. Ni L, Ye F, Cheng M-L, Feng Y, Deng Y-Q et al. Detection of SARS-CoV-2-specific humoral and cellular immunity in COVID-19 convalescent individuals. Immunity. 2020;52:971-977.

4. Vandenberg $O$, Martiny D, Rochas O, van Belkum A, Kozlakidis Z. Considerations for diagnostic COVID-19 tests. Nat Rev Micro 2021;19:171-183.

5. Deeks JJ, Dinnes J, Takwoingi Y, Davenport C, Spijker R et al. Antibody tests for identification of current and past infection with SARS-CoV-2. Cochrane Database Syst Rev 2020;6:CD013652.

6. Bastos ML, Tavaziva G, Abidi SK, Campbell JR, Haraoui L-P et al. Diagnostic accuracy of serological tests for covid-19: systematic review and meta-analysis. Brit Med J.

2020;370:m2516.

7. National SARS-CoV-2 Serology Assay Evaluation Group. Performance characteristics of five immunoassays for SARS-CoV-2: a head-to-head benchmark comparison. Lancet Infect Dis. 2020:20;1390-1400.

8. Ghaffari A, Meurant R, Ardakani A. COVID-19 Serological tests: How well do they actually perform? Diagnostics. 2020;10:453-467.

9. Whitman JD, Hiatt J, Mowery CT, Shy BR, Yu R et al. Evaluation of SARS-CoV-2 serology assays reveals a range of test performance. Nat Biotechnol 2020;38:1174-1183.

10. Wakita M, Idei M, Saito K, Horiuchi Y, Yamatani K et al. Comparison of the clinical performance and usefulness of five SARS-CoV-2 antibody tests. PLoS One. 2021;16:e0246536. 11. Tai W, He L, Zhang X, Pu J, Voronin D et al. Characterization of the receptor-binding domain (RBD) of 2019 novel coronavirus: implication for development of RBD protein as a viral attachment inhibitor and vaccine. Cell Mol Immunol. 2020;17:613-620.

12. Brouwer PJM, Caniels TG, van der Straten, K, Snitselar JL, Aldon Y et al. Potent neutralizing antibodies from COVID-19 patients define multiple targets of vulnerability. Science. 2020;3369:643-650.

13. Xiaojie S, Yu L, Lei Y, Guang Y, Min Q. Neutralizing antibodies targeting SARS-CoV-2 spike protein. Stem Cell Res. 2021;50:102125.

14. Lu S, Xie X-X, Zhao L, Wang B, Zhu J et al. The immunodominant and neutralization linear epitopes for SARS-CoV-2. Cell Reports. 2021;34:108666.

15. Lan J, Ge J, Yu J, Shan S, Zhou H et al. Structure of the SARS-CoV-2 spike receptorbinding domain bound to the ACE2 receptor. Nature. 2020;581:215-220.

16. Van Elsande J, Houben E, Depypere M, Brackenier A, Desmet S et al. Diagnostic performance of seven rapid IgG/lgM antibody tests and the Euroimmun IgA/lgG ELISA in COVID-19 patients. Clin Micro Infect. 2020;26:1082-1087.

17. Schuler CF, Gherasim C, O'Shea K, Manthei DM, Chen J et al. Accurate point-of-care serology tests for COVID-19. PLoSOne. 2020;16:e0248829.

18. Butler-Laporte, G, Lawandi A, Schiller I, Yao M, Dendukuri N et al. Comparison of saliva and nasopharyngeal swab nucleic acid amplification testing for detection of SARS-CoV-2: a systematic review and meta-analysis. JAMA Intern Med. 2021;18:353-360.

19. Azzi L, Carcano G, Gianfagna F, Grossi PA, Gasperina D Dalla et al. Saliva is a reliable tool to detect SARS-CoV-2. J Infect. 2020;81:e45-50.

20. Gupta S, Mohindra R, Chauhan PK, Singla V, Goyal K et al. SARS-CoV-2 detection in gingival crevicular fluid. J Dental Res. 2021;100:187-193.

21. Huang N, Perez O, Kato T, Mikami Y, Okuda K et al. SARS-CoV-2 infection of the oral cavity and saliva. Nat Med. 2021;27:892-903. 
medRxiv preprint doi: https://doi.org/10.1101/2021.06.28.21259657; this version posted July 3, 2021. The copyright holder for this preprint (which was not certified by peer review) is the author/funder, who has granted medRxiv a license to display the preprint in perpetuity.

All rights reserved. No reuse allowed without permission.

22. Sakaguchi W, Kubota N, Shimizu T, Saruta J, Fuchida F et al. Existence of SARS-CoV-2 entry molecules in the oral cavity. Int J Mol Sci. 2020;21:6000.

23. MacMullan MA, Ibrayeva A, Trettner K, Deming L, Das S et al. ELISA detection of SARS-CoV-2 antibodies in saliva. Sci Reports. 2020;10:20818.

24. MacMullan MA, Chellamuthu P, Mades A, Das S, Turner S et al. Detection of SARS-CoV-2 antibodies in oral fluid obtained using a rapid collection device. J Clin Micro. 2021;59:e02510e02520.

25. Pisanic N, Randad PR, Kruczynski K, Manabe YC, Thomas DL et al. COVID-19 serology at population scale: SARS-CoV-2-specific antibody responses in saliva. J Clin Micro.

2021;59:e02204-e02220.

26. Isho B, Abe KT, Zuo M, Jamal AJ, Rathod B et al. Persistence of serum and saliva antibody responses to SARS-CoV-2 spike antigens in COVID-19 patients. Science Immunol 2020;5:eabf5511.

27. Uitto V-J. Gingival crevicular fluid- an introduction. Peridontology 2000. 2003;31:9-11.

28. Griffiths, GS. Formation, collection and significance of gingival crevice fluid. Peridontology 2000. 2003;31:32-42.

29. Barros SP, Williams R, Offenbacher S, Morelli T. Gingival crevicular fluid as a source of biomarkers for periodontitis. Perioodontology 2000. 2016;70:53-64.

30. Silva-Boghossian CM, Colombo APV, Tanaka M, Rayo C, Xiao Y, Siquiera WL. Quantitative proteomic analysis of gingival crevicular fluid in different periodontal conditions. PLoS One. 2013;8:e75898.

31. Sneha V, Bhuvaneshwarri J. Recent concepts regarding gingival crevicular fluid. Eur J Mol Clin Med. 2020;7:6693-6699.

32. Subbarao KC, Nattuthurai GS, Sundararajan SK, Sujith I, Joseph J, Syedshah YP. Gingival crevicular fluid: an overview. J Pharm Bioall Sci 2019;11:S135-139.

33. Bibi T, Khurshid Z, Rehman A, Imran E, Srivastava C, Shrivastava D. Gingival crevicular fluid (GCF): a diagnostic tool for the detection of periodontal health and diseases. Molecules 2021;26:1208.

34. Sterlin D, Mathian A, Miyara M, Mohr A, Anna F et al. IgA dominates the early neutralizing antibody response to SARS-CoV-2. Sci Trans Med. 2021;13:eabd2223.

35. Qu J, Wu C, Li X, Zhang G, Jiang Z et al. Profile of immunoglobulin G and IgM antibodies against severe acute respiratory syndrome coronavirus 2 (SARS-CoV-2). Clin Infect Dis. 2020;71:2255-2258.

36. Assis R, Jain A, Nakajima R, Jasinskas A, Kahn $S$ et al. Substantial differences in SARSCoV-2 antibody responses elicited by natural Infection and mRNA vaccination. BioRxiv. https://doi.org/10.1101/2021.04.15.440089

37. Ebinger JE, Fert-Bober J, Printsev I, Wu M, Sun $\mathrm{N}$ et al. Antibody responses to the BNT162b2 mRNA vaccine in individuals previously infected with SARS-CoV-2. Nature Med. 2021;27:981-984.

38. Prendecki M, Clarke C, Brown J, Cox A, Gleeson S et al. Effect of previous SARS-CoV-2 infection on humoral and T-cell responses to single-dose BNT162b2 vaccine. Lancet.

2021;397:1178-1181.

39. Brandtzaeg P. Secretory immunity with special reference to the oral cavity. J Oral Microbiol. 2013;5:20401.

40. Dan JM, Mateus J, Kato Y, Hastie KM, Yu ED et al. Immunological memory to SARS-CoV-2 assessed for up to 8 months after infection. Science. 2021;371:eafb4063.

41. Goel RR, Apostolidis SA, Painter MM, Mathew D, Pattekar A et al. Distinct antibody and memory B cell responses in SARS-CoV-2 naïve and recovered individuals following mRNA vaccination. Sci Immunol. 2021;6:eabi6950. 
medRxiv preprint doi: https://doi.org/10.1101/2021.06.28.21259657; this version posted July 3, 2021. The copyright holder for this preprint (which was not certified by peer review) is the author/funder, who has granted medRxiv a license to display the preprint in perpetuity.

All rights reserved. No reuse allowed without permission.

\section{TABLES}

Table 1. Cross-reactivity with virus, bacteria, and auto-antibodies.

\begin{tabular}{|c|c|c|c|c|}
\hline $\begin{array}{l}\text { Virus/bacteria/autoantibody- } \\
\text { positive sample }\end{array}$ & Source & $\begin{array}{l}\text { Sample type } \\
\text { for spiking }\end{array}$ & $\begin{array}{l}\text { Number } \\
\text { reactive }\end{array}$ & $\begin{array}{c}\text { Number } \\
\text { non-reactive }\end{array}$ \\
\hline Influenza A & \multirow{16}{*}{$\begin{array}{c}\text { BiolVT, } \\
\text { Hicksville, NY } \\
\text { www.bioivt.com }\end{array}$} & Plasma & 0 & 5 \\
\hline Influenza B & & Plasma & 0 & 7 \\
\hline H. influenza & & Plasma & 0 & 8 \\
\hline Respiratory syncytial virus (RSV) & & Plasma & 0 & 9 \\
\hline Hepatitis $\mathrm{C}$ virus (HCV) & & Serum & 0 & 5 \\
\hline Hepatitis B virus (HBV) & & Serum & 0 & 5 \\
\hline Human immunodeficiency virus (HIV) & & Serum & 0 & 5 \\
\hline Alpha coronavirus $229 \mathrm{E}$ & & Serum & 0 & 20 \\
\hline Alpha coronavirus NL63 & & Serum & 0 & 17 \\
\hline Beta coronavirus OC43 & & Serum & 0 & 17 \\
\hline Beta coronavirus HKU1 & & Serum & 0 & 12 \\
\hline Enterovirus & & Plasma & 0 & 4 \\
\hline M. pneumoniae & & Plasma & 0 & 11 \\
\hline C. pneumoniae & & Plasma & 0 & 3 \\
\hline B. pertussis & & Plasma & 0 & 5 \\
\hline Parainfluenza 1-4 & & Plasma & 0 & 12 \\
\hline Rheumatoid factor (RF) & $\begin{array}{l}\text { Diabetomics, } \\
\text { Inc. }\end{array}$ & Serum & 0 & 5 \\
\hline
\end{tabular}

\section{Table 2. Demographics} of the test performance study population.

\begin{tabular}{|l|c|}
\hline \multicolumn{2}{|l|}{ Age (years) } \\
\hline $14-24$ & 15 \\
\hline $25-50$ & 123 \\
\hline $51-64$ & 58 \\
\hline $65-86$ & 50 \\
\hline Not specified & 60 \\
\hline Gender & \\
\hline Female & 112 \\
\hline Male & 156 \\
\hline Not specified & 38 \\
\hline Ethnicity & \\
\hline African-American & 36 \\
\hline Asian & 9 \\
\hline Caucasian & 108 \\
\hline Filipino & 10 \\
\hline Hispanic & 17 \\
\hline Southeast Asian & 126 \\
\hline
\end{tabular}


medRxiv preprint doi: https://doi.org/10.1101/2021.06.28.21259657; this version posted July 3, 2021. The copyright holder for this preprint (which was not certified by peer review) is the author/funder, who has granted medRxiv a license to display the preprint in perpetuity.

All rights reserved. No reuse allowed without permission.

\begin{tabular}{|l|c|c|c|c|}
\hline \multicolumn{5}{|c|}{ Table 3. CovAb ${ }^{\text {TM }}$ test positive percent agreement (PPA) and negative percent } \\
agreement (NPA).
\end{tabular}

\begin{tabular}{|l|c|c|}
\hline \multicolumn{3}{|c|}{ Table 4. Persistence of antibody } \\
response in the COVID-19-naive group.
\end{tabular}

Table 5. Agreement between RT-PCR test status and CovAb $^{\mathrm{TM}}$ test fingerstick whole blood and GCF test results.

\begin{tabular}{|c|c|c|c|}
\hline \multirow{2}{*}{$\begin{array}{l}\text { SARS-CoV-2 RT-PCR } \\
\text { test result }\end{array}$} & \multicolumn{3}{|c|}{ CovAb $^{\text {TM }}$ fingerstick test result } \\
\cline { 2 - 4 } & - & + & Total \\
\hline- & 28 & 1 & 29 \\
\hline+ & 1 & 53 & 54 \\
\hline Total & 29 & 54 & 83 \\
\hline
\end{tabular}

Positive Percent Agreement (PPA) 100x53/54=98.14\%

Negative Percent Agreement (NPA) 100x28/29=96.55\%

\begin{tabular}{|c|c|c|c|}
\hline \multirow{2}{*}{$\begin{array}{l}\text { CovAb }^{\mathrm{TM}} \text { fingerstick } \\
\text { test result }\end{array}$} & \multicolumn{3}{|c|}{ CovAb $^{T M}$ GCF test result } \\
\hline & - & + & Total \\
\hline- & 28 & 1 & 29 \\
\hline+ & 0 & 54 & 54 \\
\hline Total & 29 & 54 & 83 \\
\hline \begin{tabular}{|l} 
Positive Percent Agre \\
Negative Percent Agr
\end{tabular} & $\frac{(\mathrm{PP}}{\mathrm{t}(\mathrm{NP}}$ & $29=1$ & \\
\hline
\end{tabular}


medRxiv preprint doi: https://doi.org/10.1101/2021.06.28.21259657; this version posted July 3, 2021. The copyright holder for this preprint (which was not certified by peer review) is the author/funder, who has granted medRxiv a license to display the preprint in perpetuity.

\begin{tabular}{|l|c|c|}
\hline \multicolumn{3}{|c|}{ Table 6. Comparison of CovAbTM and Siemens EUA } \\
serology tests.
\end{tabular}

\begin{tabular}{|c|c|}
\hline $\begin{array}{l}\text { Table } 7 . \\
\text { Demographics } \\
\text { the antibody } \\
\text { response stud } \\
\text { population. }\end{array}$ & \\
\hline Age (years) & \\
\hline $14-24$ & 59 \\
\hline $25-50$ & 75 \\
\hline $51-64$ & 19 \\
\hline $65-86$ & 7 \\
\hline Gender & \\
\hline Female & 62 \\
\hline Male & 98 \\
\hline Ethnicity & \\
\hline Southeast Asian & 160 \\
\hline
\end{tabular}

\begin{tabular}{|l|c|c|c|c|c|c|c|}
\hline \multicolumn{7}{|c|}{ Table 8. Parameters of post-vaccine antibody responses. } \\
\hline Group & $\mathbf{n}$ & Negative (\%) & Positive (\%) & Median* & $\begin{array}{c}\mathbf{2 5}^{\text {th }} \\
\text { percentile* }\end{array}$ & $\begin{array}{c}\mathbf{7 5}^{\text {th }} \\
\text { percentile* }\end{array}$ & IQR $^{*}$ \\
\hline $\begin{array}{l}\text { COVID-19-naïve } \\
\text { (dose 1) }\end{array}$ & 77 & $24(33)$ & $53(67)$ & 488 & 178 & 990 & 812 \\
\hline $\begin{array}{l}\text { COVID-19-exposed } \\
\text { (dose 1) }\end{array}$ & 83 & $32(37)$ & $51(63)$ & 1163 & 360 & 1879 & 1519 \\
\hline $\begin{array}{l}\text { COVID-19-naïve } \\
\text { (dose 2) }\end{array}$ & 57 & $7(14)$ & $50(86)$ & 335.5 & 167 & 748 & 581 \\
\hline
\end{tabular}

*Values for positive samples only.

\begin{tabular}{|l|c|c|c|c|c|c|c|}
\hline \multicolumn{7}{|c|}{ Table 9. Parameters of post-vaccine antibody responses in females and males. } \\
\hline Group & $\mathbf{n}$ & Negative (\%) & Positive (\%) & Median* & $\begin{array}{c}\text { 25th } \\
\text { percentile* }\end{array}$ & $\begin{array}{c}\text { 75th } \\
\text { percentile* }\end{array}$ & IQR $^{*}$ \\
\hline $\begin{array}{l}\text { COVID-19-naïve } \\
\text { (dose 1) }\end{array}$ & & & & & & & \\
\hline Female & 35 & $8(23)$ & $27(77)$ & 799 & 170 & 1100 & 930 \\
\hline Male & 42 & $16(38)$ & $26(62)$ & 296.5 & 178 & 846 & 668 \\
\hline $\begin{array}{l}\text { COVID-19- } \\
\text { exposed (dose 1) }\end{array}$ & & & & & & & \\
\hline Female & 27 & $6(22)$ & $21(78)$ & 1075 & 307 & 1997 & 1690 \\
\hline Male & 56 & $26(46)$ & $30(53)$ & 1255.5 & 360 & 1809 & 1449 \\
\hline $\begin{array}{l}\text { COVID-19-naïve } \\
\text { (dose 2) }\end{array}$ & & & & & & & \\
\hline Female & 23 & $1(4)$ & $22(96)$ & 499.5 & 167 & 858 & 691 \\
\hline Male & 34 & $6(18)$ & $28(82)$ & 299 & 160 & 541.5 & 381.5 \\
\hline
\end{tabular}

*Values for positive samples only. 
Figure 1. Distribution of antibody responses to vaccination. A. Distribution of CovAb ${ }^{T M}$ test values in 77 COVID-19-naïve study subjects after first vaccine dose. B. Distribution of CovAb ${ }^{\mathrm{TM}}$ test values in 83 COVID-19-exposed study subjects after first vaccine dose. C. Comparison of CovAb $^{\mathrm{TM}}$ test values in COVID-19-naïve and exposed study populations. D. Distribution of $\mathrm{CovAb}^{\mathrm{TM}}$ test values in 57 COVID-19-naïve study subjects after second vaccine dose. The horizontal dotted line in each graph represents the 70 reflectance-unit threshold for a positive result based on the maximal level observed in 160 SARS-CoV-2 RT-PCR-negative GCF samples.
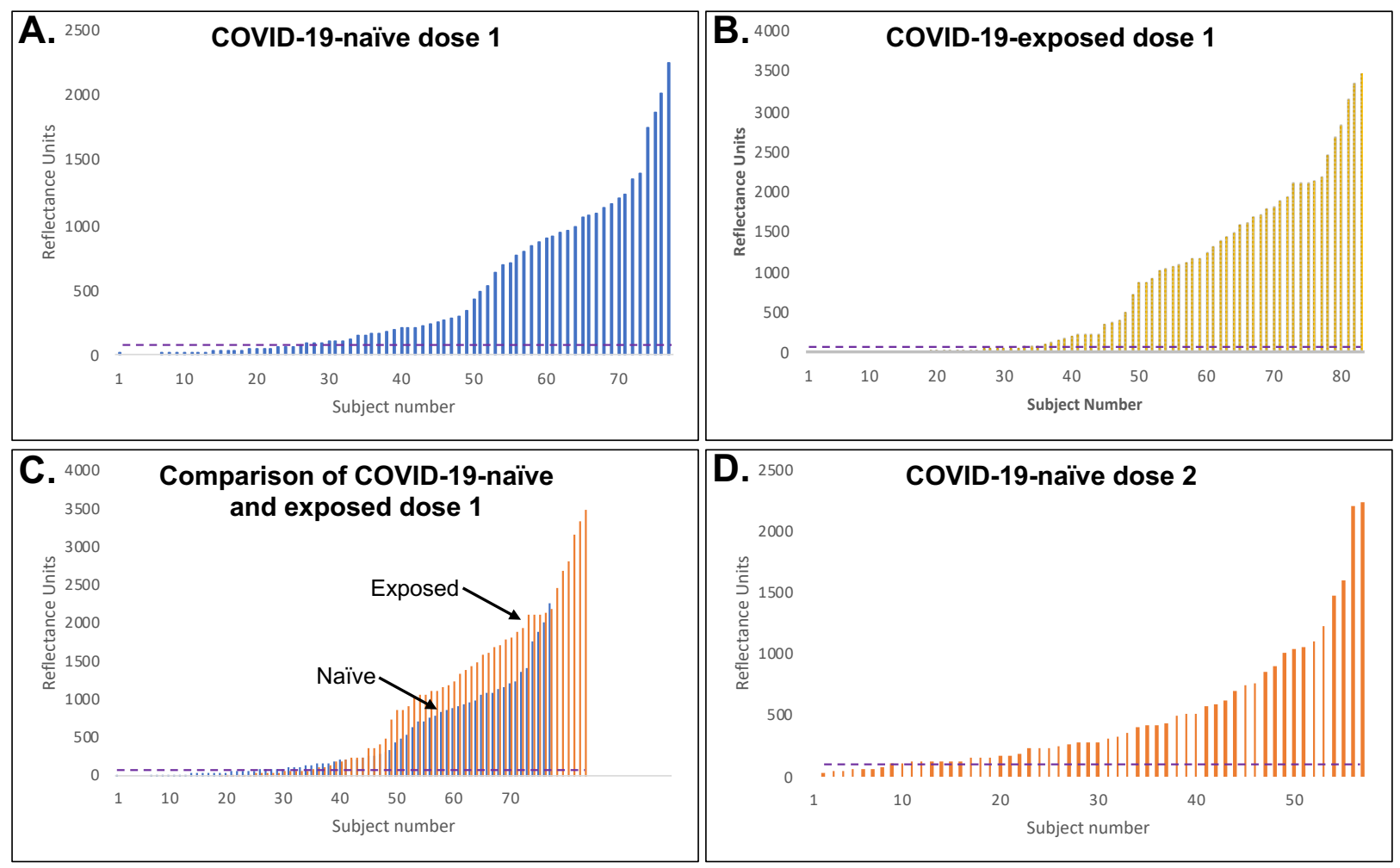
Figure 2. Antibody responses to vaccination.

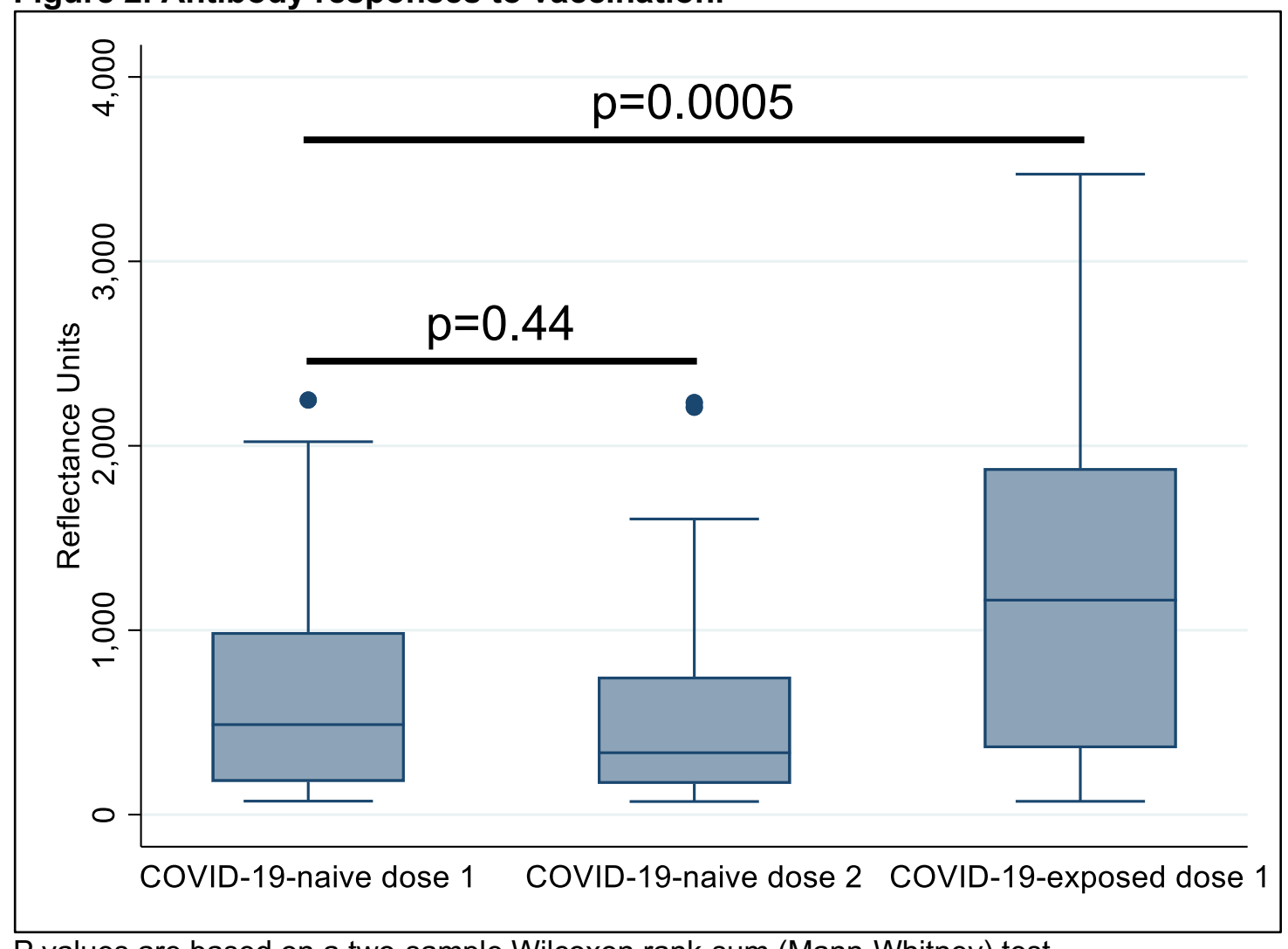

$\mathrm{P}$ values are based on a two-sample Wilcoxon rank-sum (Mann-Whitney) test. 
Figure 3. Antibody responses to vaccination in females and males.

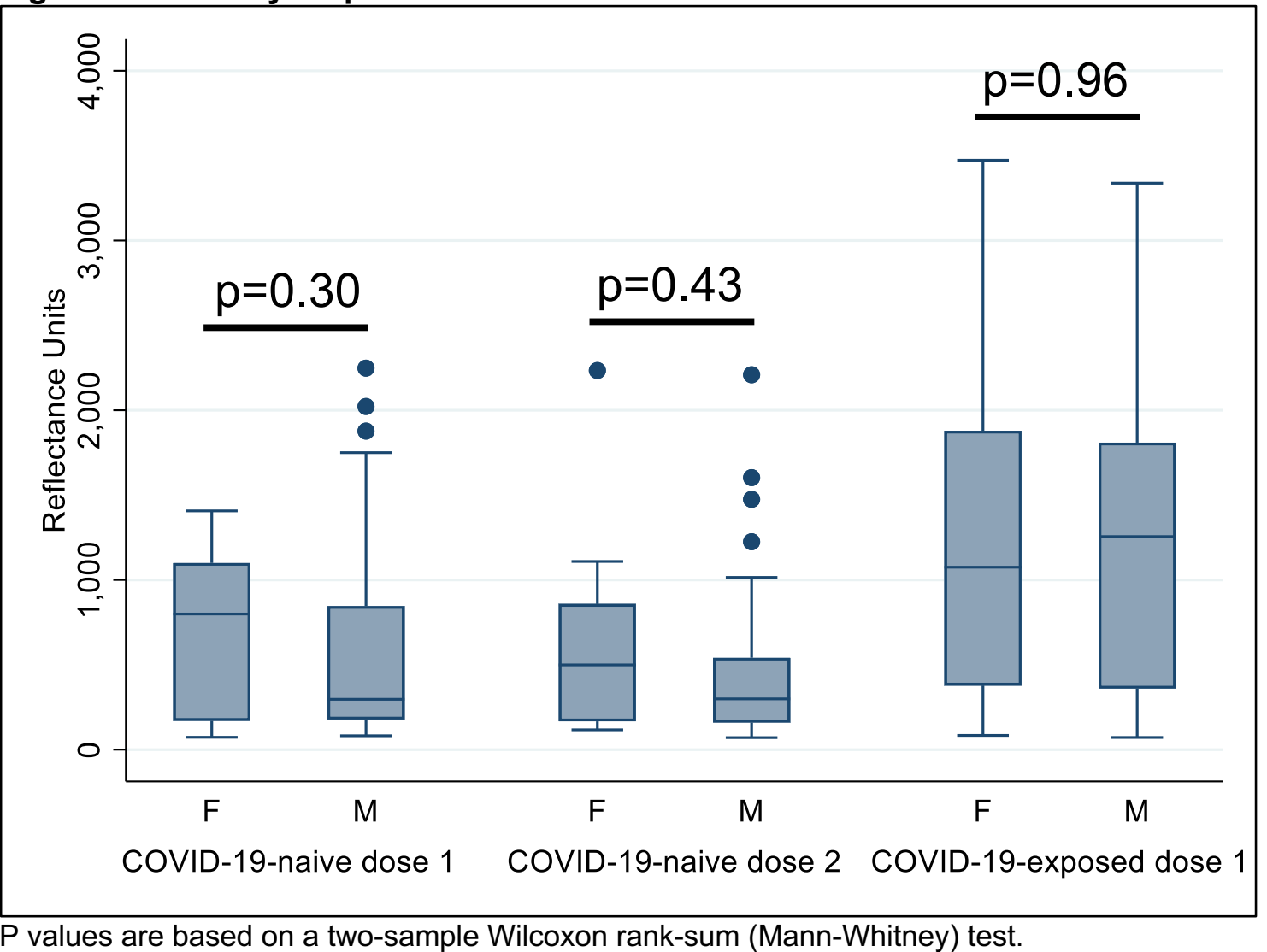

